CWI: ERH: EINK

U. S. DERARTUENT OE COMMERCE

NATIONAL BUREAU OF STANDARDS

WASHINGTON 25, D. C.

Letter

Circular

LC918

(supersedes

September 20,1948

LC 788 )

LEATHER:

Publications by Wembers of the staff of

the National Bureau of Standards

By $c$. W. Hann

I. Introduction................... I I

II. List of publications

1. Chemical and physical properties of leather. . 3

2. Development of test methods for leather. . . . 5

3. Eifect of acia on leather. . . . . . . . 6

4. Effect of moisture, gases, and heat on leather. 9

5. Sole leather............. . 10

6. Collagen ....................... II

7. Synthetic and mineral tannages......... I I

8. General iniomation on zeather and related materials............... . . 12

9. Federal specifications for leather and leather 13 products.................

\title{
I. INTRODUCIION
}

This Letter Circular lists the oublications on leather by mernbers of the staff of the National Bureau of standards and includes a list of Federal Specifications for leather and leathe products. Some of the publications in this list have appeared in the regular series of publications of this Bureau and others in various scientific and technical journals and books. Copies can 
usually be consulted at the leading libraries of large cities.

For reaũy reference and convenience in ordering the separate papers of the Bureau, these have been listed with the serial designation in one column and the price in the second column. Those marked "OP" are out of print, but may be consulted in the Iibraries as stated above. A complete list of National Bureau of Standards publications on all suojects (Circular C24 with 3 Supplements and Circular (460) is also generally available at such librartes.

Nany of the publications listed are government publications, available only from the Superintendent of Docunents, Government Priating Office, Washington 25, D. C., at the prices listed. They are not generally available from the National Bureau of standards. The prices quoted are for. delivery to addresses in the united states and its territories and possessions and in certain foreign countries which extend the iranking privilege. In the case of all other countries, one-third the cost of the publication should be added to cover postage.

For papers and publications not printed by the Government, the name of the journal or of the organization publishing the article is given in abbreviated iorm, with the volume number (underscored), page and year of publication in the order named. Information regarding their availability and price can be obtained only from the publisher or organization sponsoring the publication. Reprints of these articles are not. avallable from the Government Printing Office nor from the National Bureau of Standards with the exception of those marked with an asterisk which may be secured, wi thout charge (until the supply is exhausted) by adaressing the Leather Section, National Burcau of. Standards, Washington 25, D. C.

The National Burcau of Standards publications are issued in groups with different series designations. Each publication is readily identified by atter indicating the sories followed by a number indicating the particular pubication. The letter designanations used here are as follows:

C - "Circulari" of the National Burcau of Standards. Circulars are compilations oI information on various subjects related to the Bureau's scientific, technical, and engineering activities.

LC - "Letter Circular" of the National Bureau of Standards. These publications are mineographed, not printed like the others. This series is the only one for which requests should be sent directly to the National Bureau oi Standards. No charge is made for these publications. 
RP - "Research Paper". These are reprints of articles appearing in the "Bureau of Standards Journal of Research" and the "Journal of Research of the National Bureau of Standards", the latter being the title of this periodical since July 1934 . (volure 13, number 1).

T - "Technologic Paper" TI to T370. This series was. superseded by the "Bureau oI Standaras journal of Research"in. 1928.

* - Reprints of articles followed by an asterisk may be secured without charge (until the supply is exhausted) by addressing the Leather Section, National Bureau of Stanairds, Washington 25, D. C.

\section{LIST OF PUBLICATIONS \\ 1. CFEUICAL AND PHYSICAL PROPERTIES OF LEATHER}

Series Price

(I) Deterioration of leather under optimum mildewgrowing conditions. Joseph R. Kanagy, Robert E. Seebola, Arivelia in. Chorles, Jamos in. Cassel. J. Am. Leather Chem. Assn. to be published soon.

(2) Penetration of leather by water under aynanic . conditions. Charles E. Weir, Josephus Carter, Joseph R. Kanagy, Sanford B. Newman. J. Am. Leather Chem. Assn. 43, 69 (1948)*

(3) Adsorption of water vapor by untannea hide and various leathers at 100 degrees $F$. Joseph R. Kanagy. J: Res. NBS 迆, RPI763 loc
lig (1947). J. Am. Isather Chem. Assh. 42, 98 (1947)*

(4) Effect of mildew on vegetoble-tanned strap leather. Joseph R. Kanagy, Arbelin M. Chnrles, Edward Abrans, Roes $F_{\text {. Tener. J. Research NBS }}$ $36,441(1946)$ J. Am. Loother Cheri. Assn. 4I, $198^{\prime}\left(194^{\circ} 6^{\circ}\right)$ * RPI713 5c:

(5) A study or specifications Por chrome-tanned hydraulic-packing laathor. Ro jor' B." Ho.bos. J. Am. Leather Chom. Assn. 41, $573(19,46) *$

(6) Compression of sole leather. Chốrles E. Weir.

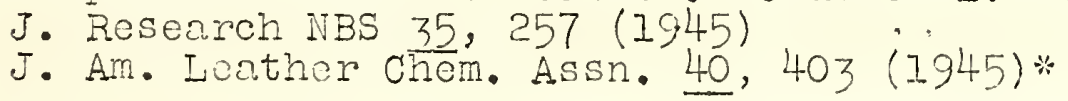
$\operatorname{RPI} 672 \quad 5 \mathrm{C}$ 
Series Price

(7.) Density oi leather and its significance. Joseph R. Kanagy and Everett L. Wallace. J. Reseärch NBS 31, 169 (1943)

J. Am. Leather Chem. Assn. 38, 314 (1943)\%

RPI556 5c

(8) Some physical and chemical tests of "belting leather. Robert B. Fobbs and Philip E. Tobias. J. Am. Leather Chen. Assn. 37, 131 (1942)*

(9) Performance tests for leather. Everett I. Wallace, Hide and Leather and Shoes. Vol. 102, No. 3 (JuIY 19, 1941).

(10) Shrinkago temperature of leather. Robert B. HobDs. J. Am. Leather Chem. Assn. 35, 272 $(1940) *$

(II) Note on the evaluation of leathor by means of the X-ray diffraction patterns. Roy C. Bowker and Harry J. INCNicholas. J. Am. Leather Chem. Assn. 34, 101 (1939)*

(12) Stability. of leather as inaicated by different Procter and searle values and by pH values. Roy C. Bowker and Everett I. Wallace, J. Arn. Leather Chem. Assn. 34, 551 (1939)\%.

(13) The probable error in the measurement of the tensile strength of heavy leather. John Beok, Jr., J. An. Leather Chem. Assn. 32, 4 (1937)*.

(14) The soluble decomposition products in aged vegetable-tanned leathers. Joseph R. Kanagy. J. Research NBS 17, 247 (19.36)

J. An. Leather Chem. Assn. 32, $12(1937) \%$

(15) Comments on the Procter and Searle method.for. detemining the acidity of vegetable-tanned leather. Roy C. Bowlror and Everett I. Wallace. J. An. Leather Chen. Assn. 29, 421 (1934).

(16) The effects of atmospheric moisture on the physical properties of vegetable and chrome tanned calf leathers. W. D. Evans and C. L. Critchfieid. BS. J.Research 11, I47 (1933)

(17) Some physical properties of fur-seal skins.

R. C. Bowker. J. Tech. Assn. Fur Ind.

ㄷ, 34 (1931). 
(18) The influence of splitting on the strength and stretch of conmercipl leathers: P." C. Bowker and E. S. Olson. J. Am. Leather Chem. Assn. 25, $275\left(1930^{\circ}\right) *$

(19) Analyses of polishing wheel lcather. R. C. Bowker. Abrașive Industry. (Jan. 1926)

(20) Efiects oI oils, greases, and aegrée of tannage on the physical properties of russet harness leather. R. C. Bowker and J. B. Churchill. Tech. Fap. BS 13 (1919-20)

(21) Analysos of different tannages of strap, harness and side leatheis. I. in. Whitmore.' J. Am. Leather Chom. Assn. 14, 567 (1919)

(22) The effect of grense on the tensile strongth of strap and harness leather. I. M. Whitmore, R. W. Hart and A. J. Beck. J. Arn. Leathor Chem. Assn.14, 128 (1919)

See also iterns (57), (65), (67).

2. DEVEIOPIENT OT DEST HETHODS FOR LEATHER

(23) Themal-density coeficients and hydrometor correction tables ior vegetabie tanning extracts. Nary Grace Blair and Elmer $L$. Pefier. J. Rẹearch NBS 33, 341 (1944)

(24) Some applications of statistical hethods to Sampling of leather. John Beels, Jr. and Robert B. Hobis. J. Am. Leather Chem. Assn. 36, $190(1947) *$

(25) An improvement in the nethod jor determining moisture in leather. Everett i. "Talneo, J. Am. Leather Chem. Assn. 36, 7 (1941)*

(26) Note on the measurement of the permeability of leather to water vapor. Robert B. Hobios. J. Am. Leather Chom. Assn. 36, 346 (1941)*

(27) Efiect of speed of pulining jows on the tensile strength and stretch of leather. Ropert 3 . Hobbs. J. Research NBS 25, 207 (1940) J. Am. Leather Chern. Assñ 35, 715 (1940)\% 
(23) Report of the A. I. C. A. Comittee on the determination of $\mathrm{pH}$ in tannery practice. Roy C. Bowker. J. An. Leather Chem. Assn. 34, 280 $(1939) *$

(29) Laboratory apparatus and method for determining the resistance of sole leather to abrasion. E. L. Wallace. J. Am. Leather chem. Assn. 32, 325 (1937)

(30) IIethods ror measuring phisical properties of leather and method of preparing samples of leather for analysis. W. E. Dmiey. J. An. Leather Chem. Assn. 32, 418 (1937)*

(31) Apparatus Ior testing coated fabrics. R. C.. Bowker. Rayon and Textile Honthly 28,57 (25) ( Jan. 1937)

(32) Method ior measuring the pH or. leather using a simple glass-electrode assembly. Everett I. . Walince. J. Research NBS 15, 5 (1935) J. Am. Leather Chem. Assn. 30, 370 (1935)

(33) A comparison of the quinhyarone and hydrogen electrodes in solutions contcining tannin. I. I. Wallace and John Beek, Jr. BS J. Rescarch 4, 737 (1930)

(34) Sampling of leather for chemical analysis. R. C. Bowker and $E$. L. Wallace. J.Am. Loather Chem. Assn. 17, 217 (1922) \%

(35) Labordtory wearing tost to determine the relative wear resistance of solo loather cut difierent depths throughout the thickness of a hide. R. N. Hart. Tech. Paper BS Iz, $(1919-20)$

$\begin{aligned} \text { See also itens } & (2),(3),(6),(9),(10),(11), \\ & (12),(13),(15),(57),(63),(72) .\end{aligned}$

$$
\text { 3. EHETCI OE AOID ON IEATHER - }
$$

(36) Influcnce of natural non-tannins on the doterioration of chestnut and quebracho leathers by sulfuric acid. Roy C. Bowker and Robert B. Hobbs. J. Am. Leather Chem. Assn. 35, 5 (1940)** 
Series Price

(37) The deterioration of leather by acid. R. C. Bowker. Stiasny Festschrift (1937). Eduard Roether Verlag, Darmstadt, Germany.

(38) Effect of acid on leatier - a sunary. Warren E. Emley. J.Ar. Leather Chem. Assn. 30, 621 $(1935) *$

(39) Deterioration of vegetable-tanned leathers con- . taining sulphuric acia and glucose. Everett $L$. Wallace and Joseph R. Kanagy. J. Research NBS $15,523(1935)$

J. An. Leather Chen. Assn. 30, 614 (1935)

$\operatorname{RP} 846 \quad 5 \mathrm{c}$

(40) Influence of sulphonated cod-liver oil on the deterioration of vegetable-tained leathers by sulphuric acid. Everett L. Wallace, Charles I. Critchfield and John Beek, Jr. J. Research NBS $15,73(1935)$

J. An. Leather Chen. Assn. 30, 438 (1935)*.

RPצII $5 \mathrm{c}$

(41) Influence of sone sulphui containing tanning naterials on the deterioration of vegetabletannod leathers by sulphuric acid. Everett L. Wallace, Joseph R. Kanagy and. Charles I. Critchifid. J. Research NBS I5, 369 (1935) J. An. Leather Chen. Assn. 30, 510 (1935)\%

RP\$35 5c

(42) Effect of sulphuric acid on chrome-tanned leather. Everett L. Wallace, John Beek, Jr., and Charles L. Critehfield.' J. Research NBS 14,771 (1935)

J. An. Leather Chen. Assn. 30, 311 (1935)\%

RP802 $5 \mathrm{C}$

(43) Influence of manesiur sulphate on the deterioration of vegetable-tanned leather by sulphuric acid. Roy C. Bowker, Everett L. Wailace and Joseph R. Kanagy. J. Rescarch NBS 14, 121 (1935) Jo An. Leather Chem. Assn. 30, 93 (1935)\%.

(44) The deterioration of vegetable-tanned leather by oxalic acid. R. C. Bowker ana J.R. Kanagy. J. An. Leather Chem. Assn. 30, 26 (1935)*

(45) Effect of temperature on the deterioration of. leather containing sulpinuric acid. R. C. Bowker and $\Xi$. L. Wallace. J. Al. Leather Chen. Assn. 29, 623 (1934)* 
(46) Report of the Comittee on the determination of acid in leather, 1934. R. C. Bowker, Chaiman, J. An. Leather Chem. Assn. 29, $403(1934)$

(47) The influence of sodiun chloride and nagnesium sulphate on the hydrolysis of leather by sulphuric acid. E. I. Wallace and J. R. Kanagy. J. An. Leather Chem: Assn. 28̂, 185:(1933)*.

(48) The influence of $\mathrm{pH}$ on the deterioration of vegetable-tanned leather by sulphuric acid. R. C. Bowker and I. L. Wallace. BS J. Research 10, 559 (1933) J.An. Le ather Chen. Assn. 28, 125 (J.933)

(49) The deterioration of Ieather by sulphuric acid as influenced by tanning with blends of chestnut and quebracho extracts. R. C. Bowler and $C$. L. Critchfield. J. Am. Ecather Chem. Assin. 27, 158 (1932)**:

(50) The adition of a definite quantity of sulphuric acid to Jeather. John Beek, Jr. J. Am. Leather Chom. Assn. 27, 79 (1932)*

(51) The effect of atmospheric noisture on the deterioration of commercial and quebracho tanned leathers containing sulphuric acid. R. C. Bowker and $W$. D. Evans. - J. Ar. Leather Chen. Assn. 27, 81 (193?)*

(52) The deteriopation of chestnut dind "quebracho tanned leathers by sulphuric acid. R. C... Bowker. J. An. Lenther Chem. Assn. 26, 444 $(1931) \%$

(53) The hydrolysis of chestnut ond quebracio tanned leathers by sulphuric acid. E. L. Wallace. BS J. Research I, 621 (1931). J. An. Leathor Chen. Assn. 26, 545*(1931)*

(54) The influence of grense on the deterioration of chestnut and quebraco leathers by sulphuric noid. R. C. Bowker. J. An. Leather Chom. Assn. 26, 667 (1931)*. 
Series Frice

(55) A study of the acisorption of sulphuric acia by

leather. John Beek, Jr. BS J. Research 5, 1109 (1930)

Ina. Eng. Chem. 22, 1373.(1930)

$R P 249$ OP

(56) Progress report on the efiects of acids on

'leather. R. C. Bowker. J. Am. Leather'Chem.

Assn. 23, 82 (1928)*.

See also item (I4).

4. EEEZCT OF NOISTURE, GASES, AND HEAT ON LEATEER

(57) Effect of temperature and time on the "weight Ioss".

of leather: J. R. Kanagy, Ao ino Charles, Jo An.

Leatier Chem. Assn. 43, 274 (1948)*

(58) Accelerated aging of lace leather. Joseph $R_{0}$

Kanagy and Philip I. Tobias. Jo'Research NBS

29, 51 (1942)

J. Am. Leather Chen. Assn. 37, 426" (1942)*

$\operatorname{RPI} 483 \quad 5 \mathrm{c}$

(59) Evolution of carbon dioxide and water from vegetable-tanned leathers at elevated temperatures. Joseph'R. Kanagy: J. Research NBS R7, 257 (19轪)

J. Am. Leather Chem. Assn。 30,609 (1941)*”

RPI4I8 5c

(60) Elfect of oxygen and mojsture on the stability

of leather at elevated temperatures. Jos éph

R. Kanagy. J. Rescarch NBS 25, 149 (1940)

J. Am. Leather Chem. Assn. 35, 632 (1940)

RPI319 5c

(61) Accelerated aging of leather"in the oxygen

bomb at 100 degrees C. Joseph R. Kanagy.

J. Researghi NBS 21, 241 (1939)

J. Am. 'Leather' chém. Assn. 33 , $565(1938) *$.

RPII28 OP

(62) Influence of copper and iron salts on the be-

havior of leather in the oxygen bomb. Joseph

R. Kanagy. J. Research NBS 20, 849 (1938)

J. An. Letather Chem: Assn. 迈, 3.52 (193\%)

RPIIO9 5c

(63) Behavior of leather in the oxygen bomb. Joseph

R. Kanagy • J. Research NBS 18, 713 (1937)

J. Am. Leather chem. Assn. 32,314 (1937)*

RP1004 5c

See.also itéms (14), (16), (45); (51): 
(64) Variation in the quality ratio for tests of sole leather in service. R. B. Hobbs. J. Am. Leather Chem. Assn. 40, 348 (7945)*.

(65) Wearing quality of some vegetable-tanned sole leathers. Robert B. Hobbs and Ruth A. Kronstadt. J. Research NBS 34, 33 (1945) J. An. Leather Chem. Assn, 40, 12 (1.945)\%

(66) Service tests of some oil-treated sole leathers. Robert B. Hobbs and Howard E. Bussey. Letter Circular LC 739 (1943)

J. Am. Leather. Chem. Assn. 39, 1.09: (1944)* Hide and Leather and Snoes IOT, No. 3, p. 21 , (Jan. i5, 1944)

(67) The physical properties of sole leather. Dorothy

Jordan Lloyd, R. C. Bowher, F. O'Flahorty, E. Norlin, J. Gordon Parker, and $\Xi$. L. Wallace. J. Int. Soc. Leather Trades' Chomists 23, 461-480 (Aug. 1939)

(68) Comparative war of chrome-tanned, vegetabletanned, and retanned sole leather. Roy C. Bowkor and Warren E. EnIey. J. Research NBS I 5,363 (1935) J. Am. Leather Chem Assn. 30, $572(1935) *$

(69) Increasing the wear of sole leather. R. C..
Bowker. Hide and Leather (oct. 19?5).

(70) Comparative durability of chrome and veretabletannea sole leathers. R. C. Bowker and $\mathrm{H}$. V. Geib. Tech. Pap. BS. $29,267,(1924-25)^{\circ} \cdot$ T286

(71) Durability of sole leathar filled with sulphite cellulose extract... R. C. Bowker.. Tech. Pap. BS 16, $495(1921-22)$. . T215

(72) An apparatus Ior measuring the relative wear of solo leathors, with rosults obtained with leather fror diferent parts of a hide. R. W. Hart and R. C. Bowker. Tech. PaD. BS $13 \cdot(1919-20)$

(73) Effects of glucose and salts on the wearing quality of solo leather. P. L. Womoley, $R$. C. Bowker, R. W. Hart, and L. The Whitriore. Tech, Pap. BS I2 (1919) 
Series Price

6. COLLAGEN

(74) Chemistry of collagen. J. R: Kanagy

NBS Circular C458 (1947) * C458 IOC

(75) The carbohydrate content of collagen. John

Beek, Jr. J. Research NBS 27, 507 (1941)

J. Am. Leather Chem. Assn. $\overline{36}, 696$ (I94I)*

$\operatorname{RPI} 43^{\circ}{ }^{\circ} \quad 5 \mathrm{c}$

J. An. Chern. Soc. 63, 1483 (1941)

76) Combination of hydrochloric acia and sodium

hydroxide with hide, tendon, and bone collagen.

John Beek, Jr. J. Research INBS 21, 117 (1939) RPIII9 5c

77) Electrophoresis of collagen. John'Beek; Jr., and Arnold W. Sookne. J. Research NBS 23,

271 (1939)

$R D 1230 \quad 5 C$

(76) Amino-nitrogen contents of wool and collagen. Joseph R. Kanagy and IIIton Harris. J. Research NBS 14, 563 (1935)

Am. Dyestuff Reporter 24, No. 7, p. 182 (1935)

$\operatorname{RP} 7 \% 7 \quad 5 c$

(79) Combining weight of collagen. John Beek, Jr. J. Research NBS I4, 217 (1935)

$R P 765 \quad 5 c$

(80) A contribution.relative to the structure of collagen. John Beek, Jr. BS J. Research

8,549 (1932)

$\mathrm{RP} 434 \quad 5 \mathrm{C}$

see also items $(3),(84)$.

7. SYNTHETIC AND MINZRAL TANAGES

(8́l) Iron as a tanning agent. Joseph R. Kanagy anà Ruth A. Kronstadt. J. Research NES 31 , $279(1943)$

J. An. Leatiner Chem. Assn. 36, $459(1943) * \quad \therefore$ RPI566 5c Hide and Leather and Shoes I06, No. $25, \mathrm{P} \cdot 29 \cdot$ (Dec. II, 1943)

(82) Action of sodium sulphate in synthetic tanning materials. W. Wolesensky. Tech. Fap. BS 20, $529(1925-26)$

(83) Analysis"of synthetic tanning materials. E. Wolesensky. Tech. Pap. BS 20, 519 (1925-26) 
(84) Behavior of synthetic tanning materials

toward hide substance. I. Wolesensky.

Tech. Pa. BS 20, 275 (1925-26)

T309

$5 c$

(85) Investigation of synthetic tanning naterials.

E. Wolesensky. Tech Pap. BS 20, $1(1925-26)$ T302 $15 \mathrm{c}$

See also items $(16),(42),(68),(70),(71),(96)$.

8. GENERAL INHORHATION ON LEATHER AND RELATED IMATERIALS

(86) Development of a fungicidal dressing for leather. J. R. Kanagy, A. IN. Charles, I. Aorans o. J. An. Leather Chem. Assn. 43 , $14(1948) \div$

(87) European footwear sizes. R. B. Hobbs. NBS Letter Circular IC 399 (1948)

$\operatorname{LC} 899$

Free

NBS

(88) Furs: general infomation. E. R. Hosteman. NBS Letter Circular LC838 (1948)

Free

LC888 NBS

(89) The Ieather industry in. China. Yu-Chih Wang. Hide and leather and shoes 114, No. 2, p. 15 (JuIy 12, 1947)*

(90) Conservation of leather shoes. R. B. Hobos. NBS Letter Circular LC719 (1943)

(91) National Bureau of Standards experimental tannery. Roy C. Bowker. Hide and Leather and shoes 97, No. 23 (June 1939)

(92) Shoe constructions, R. C. Bowker. NBS Circular C419 (1938)

(93) Analysis of salt used for curing shins. R. C. Bowker and John Beek, Jr. J.An. Leather Chem. Assn. 26, 312 (1931)*

(94) The supply of chestnut wood extract for tanning purposes. R. C. Bowker. Hide and leather (Dec. 20, 1930)

(95) Cleaning of fur and Ieathër gaments. If. H. Goldman and C. C. Hubbard. Tech. Pap. BS 22 , $183(1927-28)$ 
Series Price

(96) Use of sulphite collulose extract as a tanning material. E. L. Wallace and R. C. Eowrer. Tech. Pap. BS 21, $309(1926-27) \quad$ T339 OP

(97) Polishing leather Ior cutlery. R. C. Bowker. The Anerican cutier. (Feb. 1925)

(98) Organ and piano leathers. R. C. Bowker. The leather manuiacturor 3I, 259 (1920)

(99) Arca measurement of leather. F. J. Schlink. Tech. Pap. BS 13 $(1919-20)$

T153 OP

(100) The woris of the Bureau of Standards in

leather. P. I. Wormeley. J. Am. Leation Chen. Assin. 13, 367 (1916)

9. FEDERAL SPECIEICATIONS FOR LEATHER AND LEATHER PRODUCTS

These specifications deal with leather, leather products, or naterials used ior treating loather. Host of then wore propared by the Technical Comittee on Leather and Leather Products of the Federal Specifications Executive Committee.

\section{Title}

(101) Aprons; leather, blacksniths

(102) Bags; hand, leather

(103) Belting; fiat, loather, vegetabletannea

(104) Bëlting; round, leather, vegetabletanned, smooth

(105) Cases; brier, leather

(106) Dressing; leather, transmission-belt

(107) Envelopes; leather

(108) Holsters; pistol, leather

(109) Leather and leather products; general specifications (netinoss of sampling, inspection, and tests)

(110) Leather; bag and case
Designation Price

$K K-A-606 a \quad .5 c$

$\mathrm{KK}-\mathrm{B}-50 \mathrm{a} \quad 5 \mathrm{c}$

$K K-3-201 b \quad 5 c$

$\mathrm{KK}-\mathrm{B}-211 \mathrm{D} \quad 5 \mathrm{c}$

$\mathrm{KK}-\mathrm{C}-121 \mathrm{D} \quad 5 \mathrm{c}$

$T T-D-636 \quad 5 c$

$\mathrm{KK}-\mathrm{I}-561 \quad 5 \mathrm{c}$

$\mathrm{KX}-\mathrm{H}-566 \mathrm{a} \quad 5 \mathrm{c}$

KK-I-3II $10 \mathrm{c}$

$\mathrm{KK}-\mathrm{L}-154 \quad 5 \mathrm{c}$ 
(III) Leather aressing; mildew prevontive

(112) Leather; harness, black and russet,

(112) Leather; harness, black and russet,
(vegetable-tanned)

$0-I-I 64$

$5 c$

(113) Loather; hydraulic-packing, mineraltanned.

$K K-I-171 b$

$5 c$

$K K-L-177 a \quad 5 c$

(II4) Leather; hydraulic-packing, vegetabletanned.

$Y K-I-18 I a \quad 5 c$

(II5) Leather; Iace

$K K-I-20 I i \quad 5 c$

(116) Leather; packing, chrone-vegetable retanned.

$\begin{array}{ll}K K-I-23 I & 5 c \\ K K-I-24 I b & 5 c\end{array}$

(IIr) Leather; sole (cut, outer, and top-IiIt), vegetable-tanned, foctory

(119) Leather; strup, biack or russet

$K K-I-261 c \quad 5 c$

$K K-I-27 I D \quad 5 c$

(120) Leather; upholstery

$K K-I-291$ b

$5 c$

(121) Palms; sewing (sailmakers' and sadalens')

$\mathrm{KK}-\mathrm{P}-91$

$5 c$

(122) Polish, shoe; paste

$P-P-567$

$5 c$

(123) Satchels;-Ieather, physicians!

$K K-S-15 I a \quad 50$

(124) Skins; chanois

$K K-S-416 a$

$5 c$

(125) Soap; saddle

P-S-609

$5 c$

(126) Strops, razor; leather

$\mathrm{KK}-\mathrm{S}-756$

$5 c$

(127) Welting; leather, shoe

$\mathrm{KK}-\mathrm{W}-23 I$

$10 \mathrm{c}$

see also item (5) 